\title{
Gamma-spectrometer for water areas and bottom sediments radiation monitoring
}

\author{
Zhukouski A. ${ }^{1}$, Anshakou A. ${ }^{1}$, Biryla A. ${ }^{1}$, Chyrykala U. ${ }^{1}$, Kanavalau Y. ${ }^{1}$, Nichyparchuk A. ${ }^{1}$, \\ Savitski A. ${ }^{1}$, Khrutchinsky A. ${ }^{2}$, Kutsen S. ${ }^{2}$
}

${ }^{1} S P E \ll A T O M T E X »$,

Gikalo str., 5, 220005, Minsk, Belarus

${ }^{2}$ Institute of Nuclear Problems, Belarusian State University

Bobruiskaya str., 11, 220030, Minsk, Belarus

Received 06.10.2016

Accepted for publication 25.11.2016

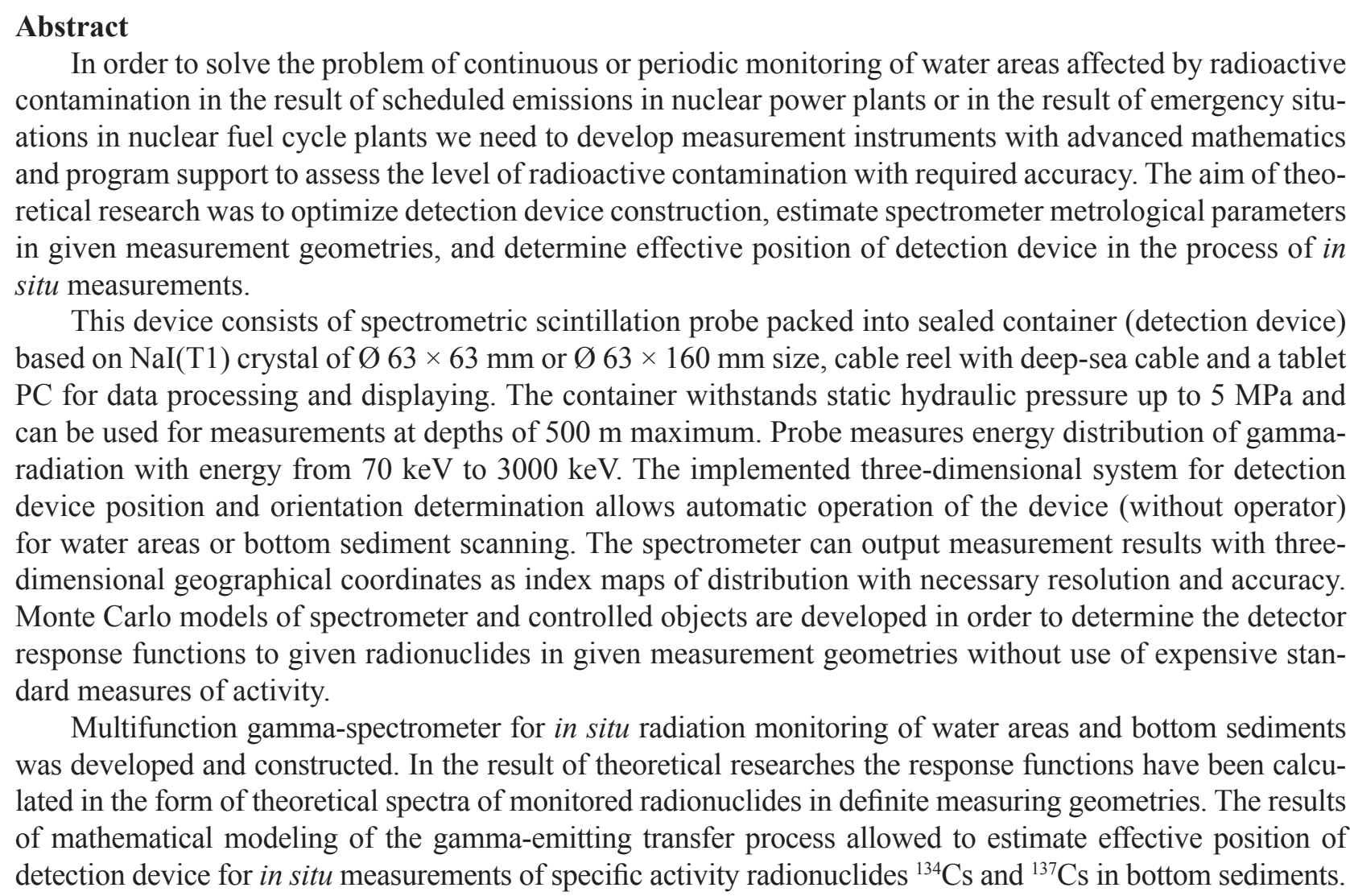

Keywords: submersible gamma-spectrometer, detection efficiency, geometry of measuring, in situ measuring.

DOI: $10.21122 / 2220-9506-2016-7-3-256-261$

\begin{tabular}{ll}
\hline Адрес для переписки: & Address for correspondence: \\
Жуковский А.И. & Zhukouski A. \\
УП «АТОМТЕХ», & SPE «ATOMTEX», \\
ул. Гикало, 5, 220005, г. Минск, Беларусь & Gikalo St., 5, 220005, Minsk, Belarus \\
е-таil: alexzhukovski@gmail.com & e-mail: alexzhukovsk@gmail.com \\
\hline Для цитирования: & For citation: \\
Zhukouski A., Anshakou A., Biryla A., Chyrykala U., Kanavalau Y., & Zhukouski A., Anshakou A., Biryla A., Chyrykala U., Kanavalau Y., \\
Nichyparchuk A., Savitski A., Khrutchinsky A., Kutsen S. & Nichyparchuk A., Savitski A., Khrutchinsky A., Kutsen S. \\
Gamma-spectrometer for water areas and bottom sediments radiation & Gamma-spectrometer for water areas and bottom sediments radiation \\
monitoring. & monitoring. \\
Приборы и методы измерений. & Priboryi metody izmerenij [Devices and Methods of Measurements]. \\
2016. - Т. 7, № 3. - С. 256-261. & 2016, vol. 7, no. 3, pp. 256-261. \\
DОI: $10.21122 / 2220-9506-2016-7-3-256-261$ & DOI: 10.21122/2220-9506-2016-7-3-256-261 \\
\hline
\end{tabular}




\title{
Гамма-спектрометр для радиационного мониторинга акваторий и донных отложений
}

\author{
Жуковский А. ${ }^{1}$, Аншаков О. ${ }^{1}$, Бирило А. ${ }^{1}$, Чирикало В. ${ }^{1}$, Коновалов Е. ${ }^{1}$, \\ Ничипорчук А. ${ }^{1}$, Савицкий А. ${ }^{1}$, Хрущинский А. ${ }^{2}$, Кутень С. \\ ${ }^{l}$ УП «ATOMTEX», \\ ул. Гикало, 5, 220005, г. Минск, Беларусь \\ ${ }^{2}$ Институт ядерных проблем Белорусского государственного университета, \\ ул. Бобруйская, 11, 220030, г. Минск, Беларусь
}

Поступила 06.10.2016

Принята к печати 25.11.2016

Задачи постоянного или периодического мониторинга водоемов, подвергшихся радиоактивномузагрязнению в результате штатных выбросов АЭС или в результате возникновения нештатных ситуаций на предприятиях топливного ядерного цикла, приводят к необходимости разработки соответствующих средств измерений с современным математическим и программным обеспечением, позволяющих оценить уровень радиоактивных загрязнений с заданной точностью. Цель теоретических исследований заключалась в оптимизации конструктива устройства детектирования, определении метрологических параметров спектрометра в заданных геометриях измерения, определении эффективного положения устройства детектирования спектрометра в процессе in situ измерений удельной активности радионуклидов ${ }^{134} \mathrm{Cs}$ и ${ }^{137} \mathrm{Cs}$ в донных отложениях с использованием разработанных Монте-Карло моделей: устройства детектирования, воды и донных отложений.

Спектрометр представляет собой многофункциональный прибор, состоящий из размещаемого в герметичном контейнере спектрометрического сцинтилляционного блока детектирования с кристаллом NaI(T1) размерами Ø $63 \times 63$ мм или Ø $63 \times 160$ мм, вьюшки с глубоководным кабелем и планшетного компьютера для обработки и отображения информации. Контейнер устойчив к статическому гидравлическому давлению до $5 \mathrm{MПа,} \mathrm{что} \mathrm{позволяет} \mathrm{проводить} \mathrm{измерения} \mathrm{на} \mathrm{глубинах} \mathrm{до} 500$ м. Устройство детектирования позволяет измерять энергетическое распределение импульсов гамма-излучения с энергией от 70 до 3000 кэВ. Реализованная система определения положения устройства детектирования в пространстве позволяет использовать спектрометр в автоматическом режиме (без участия оператора) для сканирования водной акватории и донных отложений. Результаты измерения заданной величины с трехмерными географическими координатами могут быть оперативно представлены в виде карт-схем распределения с необходимой дискретностью и точностью. Для определения функций отклика детектора к заданным радионуклидам в требуемых геометриях измерения без использования физических дорогостоящих стандартных мер активности разработаны Монте-Карло модели спектрометра и объектов контроля.

Для радиационного контроля водной среды и донных отложений методом in situ разработан и изготовлен многофункциональный портативный гамма-спектрометр. В результате теоретических исследований были рассчитаны функции отклика спектрометра к контролируемым радионуклидам в заданных геометриях измерения. Результаты математического моделирования процесса переноса гамма-излучения позволили определить эффективную позицию устройства детектирования в процессе in situ измерений активности радионуклидов ${ }^{134} \mathrm{Cs}$ и ${ }^{137} \mathrm{Cs}$ в донных отложениях.

Ключевые слова: погружной гамма-спектрометр, эффективность регистрации, геометрия измерения, in situ измерения.

DOI: $10.21122 / 2220-9506-2016-7-3-256-261$

\begin{tabular}{|c|c|}
\hline $\begin{array}{l}\text { Адрес для переписки: } \\
\text { Жуковский А.И. } \\
\text { УП «АТОМТЕХ», } \\
\text { ул. Гикало, 5, 220005, г. Минск, Беларусь } \\
\text { e-таil: alexzhukovski@gmail.com }\end{array}$ & $\begin{array}{l}\text { Address for correspondence: } \\
\text { Zhukouski A. } \\
\text { SPE «ATOMTEX», } \\
\text { Gikalo St., 5, 220005, Minsk, Belarus } \\
\text { e-mail: alexzhukovskigmail.com }\end{array}$ \\
\hline Для цитирования: & For citation: \\
\hline $\begin{array}{l}\text { Zhukouski A., Anshakou A., Biryla A., Chyrykala U., Kanavalau Y., } \\
\text { Nichyparchuk A., Savitski A., Khrutchinsky A., Kutsen S. }\end{array}$ & $\begin{array}{l}\text { Zhukouski A., Anshakou A., Biryla A., Chyrykala U., Kanavalau Y., } \\
\text { Nichyparchuk A., Savitski A., Khrutchinsky A., Kutsen S. }\end{array}$ \\
\hline $\begin{array}{l}\text { Gamma-spectrometer for water areas and bottom sediments radiation } \\
\text { monitoring. }\end{array}$ & $\begin{array}{l}\text { Gamma-spectrometer for water areas and bottom sediments radiation } \\
\text { monitoring. }\end{array}$ \\
\hline Приборы и методы измерений. & Pribory i metody izmerenij [Devices and Methods of Measurements]. \\
\hline 2016. - Т. 7, № 3. - C. 256-261. & 2016 , vol. 7, no. 3 , pp. $256-261$ \\
\hline DOI: $10.21122 / 2220-9506-2016-7-3-256-261$ & DOI: $10.21122 / 2220-9506-2016-7-3-256-261$ \\
\hline
\end{tabular}




\section{Introduction}

Water systems are an important part of the environment and are also exposed to radiation pollution as the result of accidents at nuclear fuel cycle enterprises.

Radiation monitoring of the environment, in particular, water areas and sediments, is a prerequisite for ensuring radiation safety during normal operation of nuclear power plants, as well as in the case of emergency situations at nuclear fuel cycle enterprises. Due to technological requirements nuclear power plants are located near large bodies of water (seas, lakes, large rivers) for heat removal and core cooling [1]. Events at Fukushima nuclear power plant have showed that radioactive substances fell not only on fruit and rice fields, but also in ponds and ocean, thus water pollution monitoring represents an urgent and important task [2, 3]. Significant amount of radionuclides which accumulates at the bottom as a result of sedimentation, are absorbed by fish and plants, and may eventually get into the human body [4]. Sediments radiation control is the same important task along with water radiation control.

Activity of controlled radionuclides is usually estimated by the method of representative sampling with transportation to laboratory, preparation and measurement in stationary gamma-spectrometers. Despite attempts to reduce measurement result uncertainty associated with sample selection and preparation activities for radiation control of sediments, this technique has some major disadvantages associated primarily with a high probability of random and systematic errors. Due to difficulties with obtaining of quality bottom samples and time-consuming measurement, there emerges a need for activity measurement of controlled radionuclides by in situ [5].
Specialists in many countries are developing and manufacturing submersible gamma-spectrometers for water radiation monitoring [2,5-11]. Theoretical and experimental researches presented in their works have been carried out to optimize and improve metrology and design parameters of equipment, aimed primarily for monitoring and water radiation control. At the same time, events at Fukushima nuclear power plants in 2011 have showed that determination of controlled radionuclides' activity in sediments is still a high priority task [3]. Portable and lightweight submersible spectrometers with in situ measurement functionality allows for rapid estimation of specific activity of controlled radionuclides in water and bottom sediments with required accuracy $[2,5]$.

The aim of theoretical researches have consisted in optimization of detection device construction, definition of metrological parameters of spectrometer in special measuring geometries, estimation effective position of detection device to measure specific activity radionuclides ${ }^{134} \mathrm{Cs}$ and ${ }^{137} \mathrm{Cs}$ in bottom sediments by in situ, using Monte-Carlo models of detection device, water and bottom sediments.

\section{Materials and methods}

Submersible spectrometer [12] (hereinafter spectrometer) is a modular instrument, consisting of temperature and impact resistant watertight stainless steel container (detection device) with scintillator probe based on $\mathrm{NaI}(\mathrm{Tl})$ detector of $\varnothing 63 \times 63 \mathrm{~mm}$ or $\varnothing 63 \times 160 \mathrm{~mm}$ size inside, deep water cable reel and tablet computer.

Spectrometer withstands static hydraulic pressure up to $5 \mathrm{MPa}$, which is equivalent to immersion to 500 -meter depth. The position of detection device is determined by a position sensor (gyroscope), which is used to identify the moment when the de-
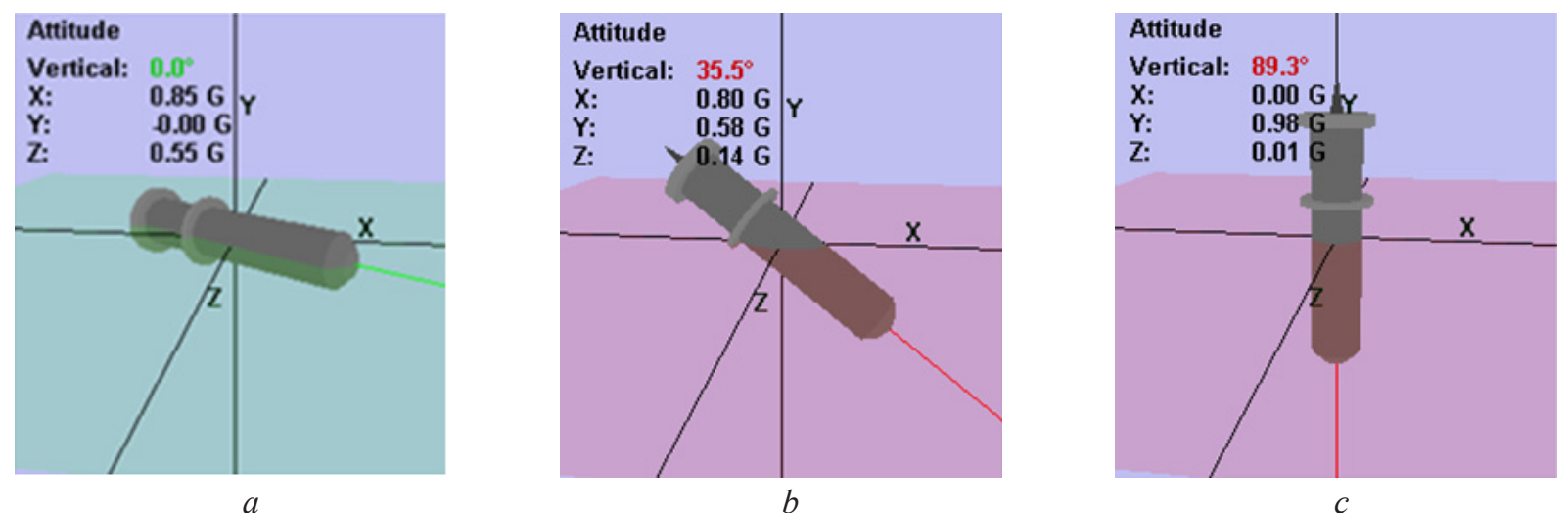

Figure 1 - Possible positions of detection device in water: $a$ - horizontal position; $b$ - intermediate position; $c$ - vertical position 
tection device contacts the bottom, and for its proper positioning (Figure 1).

Additionally, spectrometer is equipped with a pressure sensor to determine the depth of immersion and humidity sensor to control its integrity. Communication with detection device is carried out by means of cable. Data from detection device are sent to tablet computer and processed by special application software. The values of energy distribution of gamma-radiation pulses, result of radionuclides identification, specific activities of controlled radionuclide or ambient dose equivalent rate of gammaradiation are displayed on tablet computer screen.

Energy range of detected gamma-radiation, in which the energy distribution is measured, is from 70 to $3000 \mathrm{keV}$. Relative energy resolution for gammaradiation of ${ }^{137} \mathrm{Cs}(661.7 \mathrm{keV})$ does not exceed $8 \%$. Measurement range of gamma-radiation dose rate is from 0.01 to $100 \mu \mathrm{Sv} / \mathrm{h}$.

Spectrometer has internal systems for continuous automatic LED stabilization of energy scale and digital temperature compensation of measuring path. Operating temperature range of spectrometer is from $-20{ }^{\circ} \mathrm{C}$ to $+50{ }^{\circ} \mathrm{C}$.

Numerical Monte-Carlo simulation is a generally recognized solution for verification, calibration, design optimization, and definition of spectrometers' metrological parameters and basic provisions of measurement procedures, when reference materials are not available or cannot be created [13-17].

MCNP software (Monte-Carlo N-Particle Transport, Los Alamos National Labaratory, USA) of version 4A has been used for Monte-Carlo simulation [18]. At the primary stage, the detection device verification has been carried out with standard spectrometric gamma sources containing gamma-emitting radionuclides ${ }^{134} \mathrm{Cs}$ and ${ }^{137} \mathrm{Cs}$. In the course of experiment and Monte-Carlo simulation the sources were located at a distance of $5 \mathrm{~cm}$ from lateral surface of container with detection device. Amplitude deviation of full absorption peak (FAP) of gamma-radiation with energy of $661.7 \mathrm{keV}$ for ${ }^{137} \mathrm{Cs}$ as well as $597.4 \mathrm{keV}$ and $796.4 \mathrm{keV}$ for ${ }^{134} \mathrm{Cs}$ at the level of $2-3 \%$ showed a high degree of spectrometer's compliance with Monte-Carlo model.

Determination of detection device's response function to radionuclides ${ }^{134} \mathrm{Cs}$ and ${ }^{137} \mathrm{Cs}$ in given measurement geometry has been carried out using Monte-Carlo model of water in $4 \pi$ geometry and of sediment in $2 \pi$ geometry with specified radionuclide uniformly distributed in specified volume of water or sediment.

For determination of detection efficiency for specified value of gamma-radiation energy the effective volume of water has been taken into account, which is determined by the value of effective radius - radius of contaminated sphere generating more than $90 \%$ of spectrometer response function [19]. Here the tolerance of spectrometer readings for water measurement, which volume is determined by effective radius, is within the range from 5 to $10 \%$ relative to spectrometer readings for measurement of sphere with conventionally infinite radius containing gamma-photons uniformly distributed over its volume.

The results of Monte-Carlo simulation in $4 \pi$ measurement geometry in the form of calculated theoretical spectra allowed to determine the relation of detection efficiency to the energy of gamma-radiation for spectrometer based on $\mathrm{NaI}(\mathrm{Tl})$ scintillation crystal of $\varnothing 63 \times 63 \mathrm{~mm}$ and $\varnothing 63 \times 160 \mathrm{~mm}$ size (Figure 2), which is used for calculation of specific activity of most dose-forming radionuclides [20].

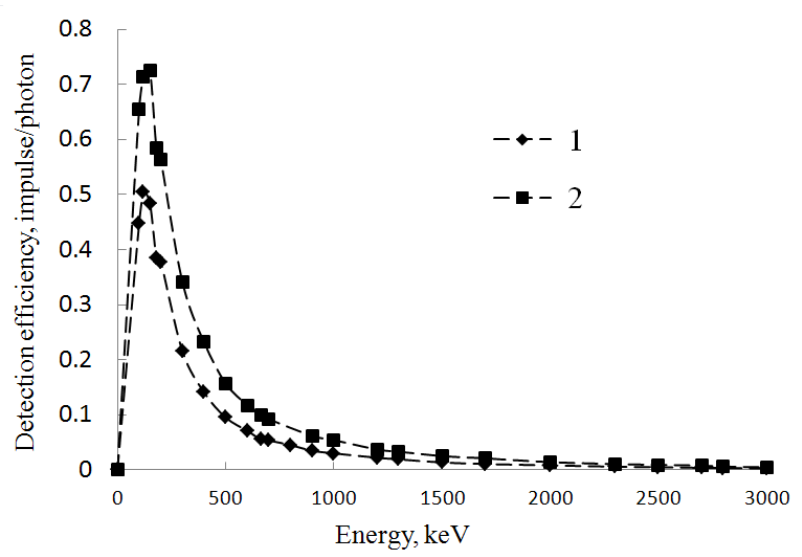

Figure 2 - The relation of detection efficiency to gammaradiation energy in $4 \pi$ measurement geometry based on $\mathrm{NaI}(\mathrm{Tl})$ scintillation detector: $1-\varnothing 63 \times 63 \mathrm{~mm}$ size; 2 - and $\varnothing 63 \times 160 \mathrm{~mm}$ size

One of the most important spectrometer's parameters in any geometry is sensitivity to measured radionuclide or relation of detection efficiency to energy of gamma-radiation. Spectrometer's detection limit depends on this metrology parameter along with mathematical algorithm of processing of gamma-impulse energy distribution. In order to set requirements for sediment radiation control methods and find optimal detection device position relative to the object of control in which the spectrometer demonstrates maximum sensitivity to controlled 
radionuclides. Monte-Carlo model of detection device and contaminated bottom sediments with contaminated layer thickness $\mathrm{D}=10 \mathrm{~cm}$ has been used (Figure 3).

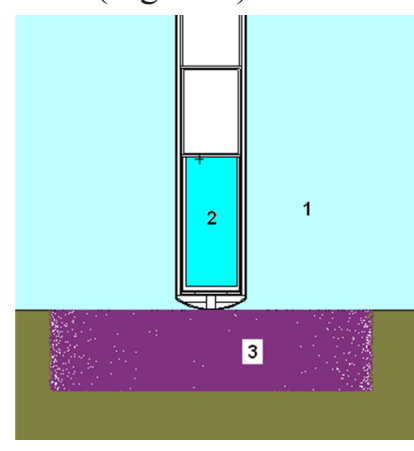

$a$

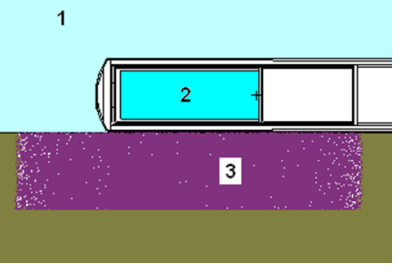

$b$
Figure 3 - Monte-Carlo model of detection device and contaminated bottom sediments in in situ measurement geometry: $a$-Vertical; $b$ - Horizontal. 1 - Seabed layer of water; $2-\mathrm{NaI}(\mathrm{Tl})$ detector of $63 \times 160 \mathrm{~mm}$ size; 3 - Bottom sediments

The density of Monte-Carlo sediment model has been taken as $1.3 \mathrm{~g} / \mathrm{cm} 3$. See Table [19] for elemental composition of sediments used in simulation of gamma-radiation transfer in $2 \pi$ measurement geometry.

Table

Elemental composition of sediments

\begin{tabular}{cc}
\hline Chemical element & $\mathrm{W} / \mathrm{w}, \%$ \\
\hline $\mathrm{Si}$ & 24.32 \\
\hline $\mathrm{Al}$ & 5.07 \\
\hline $\mathrm{Fe}$ & 1.04 \\
\hline $\mathrm{Ca}$ & 0.31 \\
\hline $\mathrm{Mg}$ & 0.62 \\
\hline $\mathrm{K}$ & 1.21 \\
\hline $\mathrm{Na}$ & 1.08 \\
\hline $\mathrm{O}$ & 62.18 \\
\hline $\mathrm{P}$ & 0.03 \\
\hline $\mathrm{S}$ & 0.07 \\
\hline $\mathrm{C}$ & 3.53 \\
\hline $\mathrm{H}$ & 0.38 \\
\hline $\mathrm{N}$ & 0.19
\end{tabular}

Figure 4 shows the dependence of integral spectrometer response from the radius of sediment site contaminated by ${ }^{137} \mathrm{Cs}$ radionuclide for detection device based on $\mathrm{NaI}(\mathrm{Tl})$ scintillation crystals of $\varnothing 63 \times 63 \mathrm{~mm}$ and $\varnothing 63 \times 160 \mathrm{~mm}$ size when placing the detection device vertically and horizontally relative to the source of gamma-radiation.

Seabed layer of water has a significant impact on detector response function during in situ measurements of sediments. Seabed water layer diffuses and weakens gamma-radiation emitted from the source (sediment layer contaminated by radionuclides) in detector direction. Scattered gamma-photons make additional contribution to low-energy part of spectrometer response function. This effect increases when detection device is used according to the scheme shown in Figure $4 a$ with detection device based on scintillation crystal, which length exceeds its diameter. In this case integral response in the form of response function increases, resulting in reduced detection limit, while significant increase of scattered component introduces additional error into determination of thickness of contaminated sediment layer. Such factors as small effective area of gamma-radiation source relative to the size of the scintillation crystal, lower value of scattered component of instrument spectrum relative to response in FAP, higher sensitivity of measurement by side spectrometer's surface demonstrate the advantages of measurement of contaminated sediments according to scheme shown in Figure $4 b$. Also, fast and accurate determination of measurement start (Horizontal position on the bottom) allows reduction in time required to carry out measurements at check point.

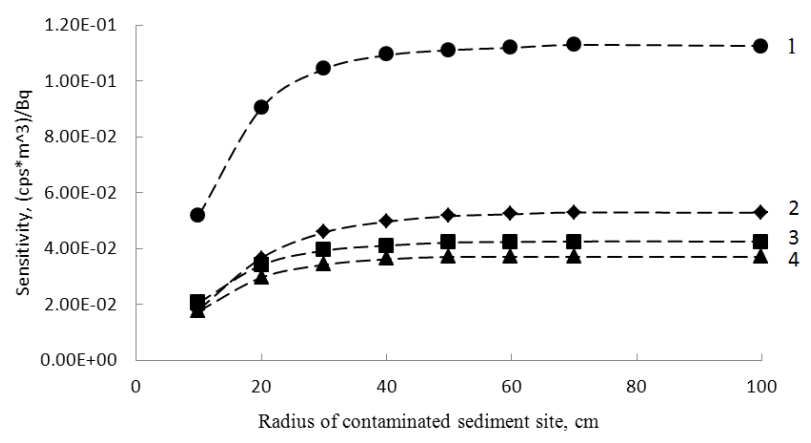

Figure 4 - Dependence of integral spectrometer response from the size of contaminated sediment site: 1 - horizontal position of detection device based on $\mathrm{NaI}(\mathrm{Tl})$ crystal of $\varnothing 63 \times 160 \mathrm{~mm}$ size; 2 - vertical position of detection device based on $\mathrm{NaI}(\mathrm{Tl})$ crystal of $\varnothing 63 \times 160 \mathrm{~mm}$ size; 3 - horizontal position of detection device based on $\mathrm{NaI}(\mathrm{Tl})$ crystal of $\varnothing 63 \times 63 \mathrm{~mm}$ size; 4 - vertical position of detection device based on $\mathrm{NaI}(\mathrm{Tl})$ crystal of $\varnothing 63 \times 63 \mathrm{~mm}$ size

\section{Conclusion}

The peculiarity of the conducted researches is in the application of Monte-Carlo simulation method in the achievement of the objectives. 
Monte-Carlo models of detection devices, water and sediments have allowed determination of necessary spectrometer response function in the form of spectra of controlled radionuclides in required measurement geometries.

The results of theoretical research allowed determination of metrological parameters of detection devices based on $\mathrm{NaI}(\mathrm{Tl})$ scintillation crystals of $\varnothing 63 \times 63 \mathrm{~mm}$ and $\varnothing 63 \times 160 \mathrm{~mm}$ size in basic measurement geometries $(2 \pi$ and $4 \pi)$ and establishing a set of rules and procedures for specific activity measuring of controlled radionuclides without sampling and preparation of water and sediment samples.

\section{References}

1. Grishin D.S., Kuchin N.L., Kiziurov V.C., Laykin A.I., Miheev U.V., Triumphov N.H., Chistiakov O.B., Kharitinov I.A. [Submersible gammaspectrometers - the application experience and prospects of using]. ANRI, 2016, no. 2, pp. 10-21 (in Russian).

2. Thornton B., Ohnishi S., Ura T., Odano N., Sasaki Sh., Fujita Ts.,Watanabe T., Nakata K., Ono Ts., Ambe D. Distribution of local 137Cs anomalies on the seafloor near the Fukushima Dai-ichi Nuclear Power Plant. Marine Pollution Bulletin, 2013, no. 74, pp. 344350. doi: 10.1016/j.marpolbul.2013.06.031

3. Zhukouski A., Chirikalo V., Guzov V., Kozhemyakin V., Kutsen S., Khrutchinsky A., Fukuhara T., Yajima T., Mogi M., Mogi K., Chudakov V. AT6104DM gamma-spectrometer for radiation monitoring water areas and bottom sediments. Results of mathematical and experimental researches. Problemy prikladnoj spektrometrii $i$ radiometrii [Problems of applied spectroscopy and radiometry], St. Petersburg, 2015, pp. 160-163.

4. Appleby L.J., Dewell L., Mishara Yu.K. The ways of migration of artificial radionuclides in the Environment. In F. Warner and Harrison (eds.). Moscow, Mir Publ., 1999, pp. 512 (in Russian).

5. Kazennov A.Y, Hapanov I.A., Pimenov A.E. [Methods of operational radiation surveys of coastal waters fleet bases with the help of submersible gammaspectrometers]. Atomnaya energiya [Atomic energy], 2010, vol. 9, no. 2, pp. 100-108 (in Russian).

6. Jones D.G. Development and application of marine gamma-ray measurements: a review. Journal of Environmental Radioactivity, 2001, no. 53, pp. 313-333.

7. Vlastou R., Ntziou I.Th., Kokkoris M., Papadopoulos C.T., Tsabaris C. Monte-Carlo simulation of $\gamma$-ray spectra from natural radionuclides recorded by a $\mathrm{NaI}$ detector in the marine environment. Applied Radiation and Isotopes, 2006, no. 64, pp. 116-123.

doi: $10.1016 /$ j.apradiso.2005.07.011
8. Aakenes U.R., Radioactivity monitored from moored oceanographic buoys. Chemistry and Ecology, 1995, no 10,pp. 61-69. doi: 10.1080/02757549508035330.

9. Baranov I., Kharitonov I., Laykin A., Olshansky Yu. Devices and methods used for radiation monitoring of sea water during salvage and transportation of the Kursk nuclear submarine to dock. Accelerators, Spectrometers, Detectors and Associated Equipment, Section A, 2003, no. 505, pp. 439-443. doi: 10.1016/S0168-9002(03)01116-1

10. Wedekind C., Shilling G., Güttmüller M., Becker K. Gamma-radiation monitoring network at sea. Applied Radiation and Isotopes, 1999, no. 50, pp. 733- 741. doi: 10.1016/S0969-8043(98)00062-1

11. Povinec P.P., Osvath I., Baxter M.S. Underwater gamma-spectrometry with $\mathrm{HPGe}$ and $\mathrm{NaI}(\mathrm{Tl})$ detectors. Applied Radiation and Isotopes, 1996, no. 47, pp. $1127-$ 1133. doi: 10.1016/S0969-8043(96)00118-2

12. Birila A., Chirikala V., Zhukouski A. Spektrometr pogruzhnoj [Submersible Spectrometer]. Patent BY no. $3278,2015$.

13. Zhukouski A., Mogi K., Kutsen S. [In situ measurement of soil radioactivity]. Vestsi NAN Belarusi, Fiziko-tekhnicheskaya seriya [Proceeding of the National academy of sciences of Belarus, physico-technical series], 2016, no. 3, pp. 105-110 (in Russian).

14. Zhang Y., Li Ch., Liu D., Zhang Yi., Liu Ya. Monte-Carlo simulation of a $\mathrm{NaI}(\mathrm{Tl})$ detector for in situ radioactivity measurements in the marine environment. Applied Radiation and Isotopes, 2015, no. 98, pp. 44-48. doi: $10.1016 /$ j.apradiso.2015.01.009

15. Kinchakov V.S. Performance optimization of a deep-sea scintillation gamma detector. Technical Physics, 2006, vol. 51, no. 1, pp. 134-138.

doi: $10.1134 / \mathrm{S} 106378420601021 \mathrm{X}$

16. Dreyzin V.E., Sideleva N., Logvinov D. [Simulation instrumental gamma spectra of scintillation detector using a macro approach]. ANRI, 2014, no. 3, pp. 2-12 (in Russian).

17. Bagatelas C., Tsabaris C., Kokkoris M., Papadopoulos C.T., Vlastou R. Determination of marine gamma activity and study of the minimum detectable activity (MDA) in $4 \pi$ geometry based on Monte-Carlo simulation. Environmental Monitoring and Assessment, 2010, no. 165, pp. 159-168. doi: 10.1007/s10661-009-0935-4

18. Briestmeister J.F. Ed. MCNP- A general MonteCarlo N-particle transport code, Version 4A. Report LA12625-M, Los Alamos. NM, Los Alamos National Laboratory, 1994.

19. Zhukouski A., Kutsen S., Khrutchinsky A., Tolkachev A., Guzov V., Kojemiakin V., Chudakov V. [Evaluation of the area of influence of the contaminated soil region in solving the problems of radiation monitoring by in situ]. Pribory i metody izmerenij [Devices and Methods of Measurements], 2014, no. 1 (8), pp. 119-124 (in Russian).

20. Yekidin A.A., Zhukovski M.V., Vasianovich M.E. [Identification of the main dose-forming radionuclides in nuclear power plant emissions]. Atomnaya energiya [Atomic energy], 2016, vol. 120, no. 2, pp. 106-108 (in Russian). 